\title{
A STUDY ON ESTIMATION OF PEDESTRIAN PROXIMITY PROBABILITY IN AN ATRIUM INSIDE A STATION DURING THE COVID-19 PANDEMIC USING AGENT-BASED SIMULATION
}

\author{
エージェント・ベースド・シミュレーションを用いたCOVID-19 パンデミック期間中の \\ 駅構内アトリウムにおける歩行者の近接確率の評価に関する研究
}

\author{
Yuanyuan LIU ${ }^{* 1}$ and Toshiyuki KANEDA*2 \\ 劉原原, 兼田敏之
}

\begin{abstract}
This paper develops an ABM tool to estimate pedestrian proximity probability with a contagious pedestrian in a station atrium during the COVID-19 pandemic and explore an agent-oriented modeling and simulation framework for emergency space planners and designers. Comparative video analysis before and during the pandemic is conducted, and pedestrian avoidance behavior is divided into PSA (personal spacing avoidance) and LRA (long-range avoidance) for detailed examination. Agent Simulator of Contagious Pedestrian Proximity (ASCPP) was developed to analyze the influence of pedestrians' 'distancing' awareness, maskwearing, and standing pedestrians.
\end{abstract}

Keywords : Physical distancing, COVID-19, Proximity probability, Agent-based modeling, Atrium in a station, Spatial analysis フィジカル・ディスタンシング, COVID-19, 近接確率, エージェントベースモデリング, 駅構内アトリウム, 空間分析

\section{Research Background And Objective}

With the recent global COVID-19 pandemic, physical distancing measures have been commonly applied. Recent research shows that physical distancing may be necessary into 2022 or even longer ${ }^{1)}$. Policymakers must tighten and relax public gathering policies according to the pandemic situation to balance the economy and people's health.

This paper develops an ABM tool to estimate proximity probability with a contagious pedestrian in an atrium inside a station during the COVID-19 pandemic using agent-based simulation. Even though many infectious models have been made to estimate the transmission of COVID-19, there are not enough models estimating people's interactions in a specific space. While keeping people at a distance is more accessible in a stationary scenario, it is harder to follow the distancing regulations since the pedestrian environment is ever-changing. In addition, the pedestrian planning and capacity design for most spaces use standards from the pre-pandemic period, and there is no published quantitive study considering pedestrian proximity probability in public space. This study conducted a comparative video analysis before and during the pandemic and divided the pedestrian avoidance behavior into PSA (personal spacing avoidance) and LRA (long-range avoidance). Based on the findings, an Agent Simulator of Contagious Pedestrian Proximity (ASCPP) was developed. The pedestrian proximity probability to a contagious agent will be examined under free walking and similar flow conditions within the specific space layout. The influence of the presence/absence of pedestrians' 'distancing' awareness, mask-wearing, and standing pedestrians are simulated and analyzed.

\section{Related Studies}

In this section, we review relevant studies on the general features of the COVID-19 pandemic, global physical distancing policies and recommendations, and the application of ABM in the field of density control in indoor public spaces.

*1 Ph.D. Candidate, Graduate School of Engineering, Nagoya Institute of Technology, M.Eng.

"2 Prof., Graduate School of Engineering, Nagoya Institute of Technology, Dr.Eng.

名古屋工業大学大学院工学研究科 博士後期課程 $\cdot$ 修士 (建築学 $\cdot$ 工学) 名古屋工業大学大学院工学研究科 教授・工博 
Respiratory infectious diseases, including COVID-19, are transmitted via large droplets and small droplets (aerosols) ${ }^{2)}$. Recent research has shown that exhalations, sneezes, and coughs are made of a multiphase turbulent gas cloud carrying pathogen-bearing droplets. The gas cloud allows droplets to travel as far as 23 to 27 feet (7.01 to $8.23 \mathrm{~m}$ ) when sneezing ${ }^{3)}$. Recent experimental research shows that a heavy cough jet can reach $3.66 \mathrm{~m}$, and the average cough jet can reach $2.44 \mathrm{~m}$ when the face is uncovered ${ }^{4}$. This research also reveals that the average air leak can travel $0.20 \mathrm{~m}$, even wearing a non-woven mask. Those studies prove the necessity of personal protection equipment and address that the exposure degree varies tremendously according to the proximity degree. In the general understanding, transmission probability is decided by the proximity and exposure time to a contagious individual ${ }^{5)}$, 6).

The conventional infectious disease modeling approaches include mathematical models, system dynamics models, discrete-event simulations, data-driven modeling, machine-learning techniques, and so on ${ }^{7}$. Among those models, many operate on global, national, or regional scales based on an epidemic's transmission probability. Analysis and predictions at a finer resolution are required to support the decision-making on local and even facility-level scales ${ }^{8}$. With ABM, it is possible to build scenarios under a pandemic situation, including individual behaviors. Few studies have yet contributed to COVID-19 modeling using ABMs. D'Orazio et al. modified existing ABMs with a rough simulation step setup (15 minutes) to estimate the virus spreading in touristic areas and closed buildings ${ }^{5)}$, 9). They evaluated riskmitigation measures such as physical distancing and mask implementation. Cuevas proposed an ABM to evaluate the COVID-19 transmission risks in facilities highlighting the individual contact patterns ${ }^{8}$. The transmission probability in their ABM depends on both individual's health condition and discipline in following prevention measures. Muller proposed an ABM that combines mobile phone data with a mechanistic infection model and a disease progression model ${ }^{10}$ ). This model shows how different activity types contribute to infection dynamics over time. It should be mentioned that the phone data trajectories in this study are synthetic approximations for the complete population for privacy reasons. Although those models contributed with different techniques and scenarios, specific individual avoidance behaviors and real interactions are replaced by probability calculations. Our model contributes to analyzing pedestrian avoidance behavior before and during the COVID-19 pandemic with real-life pedestrian videos, emphasizing spatial aspects and quantitively evaluating the proximity degree.

Physical distancing policies and advice vary worldwide under different considerations. In the WHO Coronavirus disease advice for the public, people are suggested to maintain at least $1 \mathrm{~m}$ distance between each other ${ }^{11)}$. The Centers for Disease Control and Prevention of the United States (CDC) recommends a physical distance of about six feet / $2 \mathrm{~m}^{12}$. People are advised to keep at least a $2 \mathrm{~m}$ distance from others in Japan and avoid the three Cs (crowded places, close-contact settings, and closed spaces) ${ }^{13)}$.

To distinguish the 'distancing' awareness because of the pandemic, we reviewed studies on human distances. Hall has divided distances into four categories: intimate, personal, social, and public. Personal distance, ranging from $0.46 \mathrm{~m}$ to $1.22 \mathrm{~m}$, provides a small protective sphere around the human body. Social distance, ranging from $1.22 \mathrm{~m}$ to $3.66 \mathrm{~m}$, provides the "limit of domination" 14). Fruin also gives a definition of social distance: "Social distance, or the circle of personal involvement, begins at an inter-person spacing of 12 feet (3.66 m)" 15 ). Golas et al. proposed a hybrid algorithm for collision avoidance with transitions between continuum and discrete representations for crowd simulation in prior work. The purpose of this algorithm is to save computational costs by clustering distant agents ${ }^{16)}$. Currently, there are not many studies focusing on pedestrians' long-range avoidance behavior.

The previous studies have studied many influential factors for avoidance behaviors. A unidirectional walking experiment study done by Tatebe et al. shows the avoidance distance from pedestrians to an obstacle or a standing pedestrian is determined by the sum of the distance to keep personal space, the distance caused by the pedestrian's forward movement, and the distance exerted by the forecasted movement of an obstacle ${ }^{17}$. A following unidirectional empirical study shows that selecting the point where the curvature in the walking trajectory is biggest defines the beginning point of avoidance behavior ${ }^{18)}$. Tang et al. found that direction and time period (commuting and noncommuting hours) are essential correlative factors of people-to-people avoidance distance. Other correlative factors also include general variables like speed, density, space characteristics, and personal variables like gender, age, and stature. The concept of avoidance behavior ahead of time is also mentioned in this study ${ }^{19}$. The following study revealed that avoidance behavior shows significant differences between pedestrians moving in the opposite direction and the same direction ${ }^{20)}$.

Based on the above literature, we define the concepts used in the following analysis: Pedestrian proximity probability measures the chance

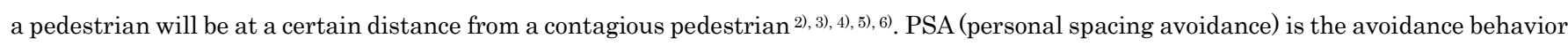
starting at a distance of fewer than $3.66 \mathrm{~m}$. Corresponding to PSA, the avoidance behavior that begins at a distance longer than $3.66 \mathrm{~m}$ is defined as LRA (long-range avoidance) behavior ${ }^{14)}$, 15). All the physical distancing policies are consistent with the distance of PSA 11), 12), 13). We distinguish between PSA and LRA mainly by considering the reason for avoidance. In a conventional concept, avoidance is the evasion of physical contact and keeps the pedestrian in a comfortable zone. Along with the physical distancing policies and concern about infections, we wonder if pedestrians have manifested their 'distancing' awareness in daily movement. 


\section{Methodology}

This research first conducted a video analysis of pedestrian avoidance behavior in an atrium inside Nagoya Station in June 2020, under the COVID-19 pandemic situation. Then, a video in the same location in June 2015 from different research was analyzed as an ordinary situation. As will be detailed in a later section, we extracted pedestrians' avoidance distance, lateral displacement offset, and avoidance rate of PSA and LRA behaviors from videos taken from both years. Based on the extracted data, we build an Agent Simulator of Contagious Pedestrian Proximity (ASCPP), with pedestrian walking rulesets extracted from the pandemic and ordinary situations. The concept of pedestrian proximity zone is developed by examining the relevant studies. Pedestrian proximity probability with a contagious agent is estimated in each pedestrian proximity zone. Simulation scenarios were designed considering the presence/absence of pedestrians' 'distancing' awareness, the mask-wearing population, and standing pedestrians as influential factors. The results are discussed, focusing on each scenario's degree of effect on an agent's proximity probability.

\section{Data Collection}

This section introduces the data collection location and time. The Golden Clock atrium is an indoor public space inside Nagoya Station. Fig.1 shows the spatial layout of this atrium and the video-recording spot. The atrium contains four entrances/exits, named A to D in this study, and has an entire area of $32 \times 34 \mathrm{~m}$. Fig. 2 is a snapshot of the sight field from the video-recording spot from an overhanging space on the second floor. We recorded a five-minute video clip from 8:00 to 20:00 every two hours on a weekday and a weekend in June 2020. Our comparative video clips are from a different study recorded in the same atrium in $2015^{21}$. We excluded the commuting hours and pedestrians congested video clips after comparing the pedestrian walking behaviors and the density levels. There are two reasons for this exclusion: 1) The 2015 video clips were recorded in non-commuting hours and had no apparent pedestrian congestion; 2) Our analysis focuses on the microscopic behavioral difference in the COVID-19 pandemic when pedestrians are under free walking and similar conditions of $0.0-0.5$ people $/ \mathrm{m}^{2}$. Eventually, two five-minute videos recorded between 14:00 to 15:00 on June 8, 2020, and the comparison video recorded between 19:00 to 20:00 on June 5, 2015 were selected as main video clips. The video clips recorded from other time zones are kept as supplementary video clips.

Table1 presents a full sampling origin-destination (OD) matrix of the two main video clips in 2015 and 2020. This table presents the number of pedestrians in fields initially, the pedestrians can be tracked to the OD matrix and the pedestrians in fields at the end of the video clips. The OD matrix shows that a large ratio of pedestrians moves between entrance/exit $\mathrm{A}$ to $\mathrm{C}$, and the pedestrian flow is mainly bidirectional. This bi-directional flow with a low possibility of walking conflict is easier to distinguish between pedestrians' 'distancing' behavior within the pandemic context. That is why we chose the area between entrance/exit $\mathrm{A}$ and $\mathrm{C}$ instead of the area between entrance/exit $\mathrm{B}$ and $\mathrm{D}$, which has a diagonal flow of pedestrians walking from entrance/exit A and D. A density-speed measurement area is set in the middle of the atrium.

We also counted the mask-wearing ratio among the population in the pandemic case. Among the 100 pedestrians selected randomly, 90\% were wearing a mask. Most of them were commercial non-woven masks, and a small percentage were handmade masks.

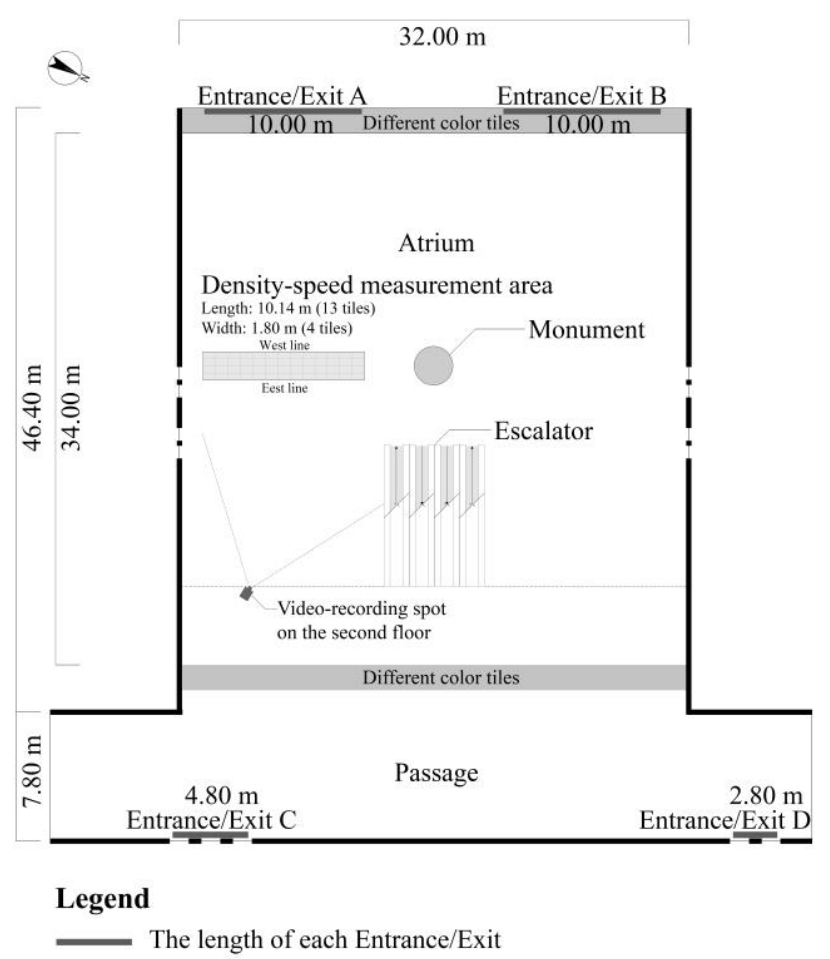

Fig.1 Spatial layout of the atrium

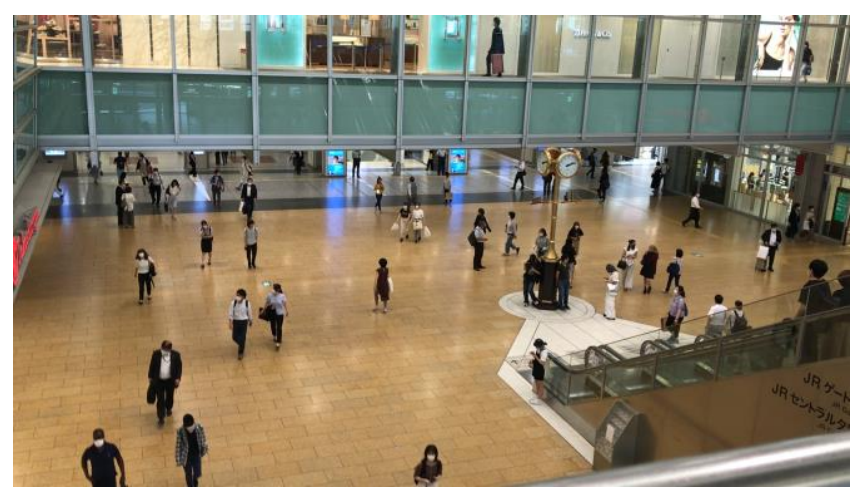

Fig.2 Sight field from the video-recording spot in 2020 
Table1 Pedestrian origin-destination matrix measured in 2015 and 2020

\begin{tabular}{|c|c|c|c|c|c|c|c|c|c|c|c|c|c|c|c|c|c|c|c|c|c|}
\hline \multicolumn{11}{|c|}{2015 ordinary situation (five-minute measured value) } & \multicolumn{11}{|c|}{2020 pandemic situation (five-minute measured value) } \\
\hline \multirow{2}{*}{\multicolumn{2}{|c|}{ From }} & \multirow[t]{2}{*}{ In fields $\alpha^{*}$} & \multirow[t]{2}{*}{ Inflow $B$} & \multicolumn{6}{|c|}{ Outflow Y: Exit } & \multirow{2}{*}{$\begin{array}{c}\text { In fields } \\
\delta \\
\end{array}$} & \multirow{2}{*}{\multicolumn{2}{|c|}{ From }} & \multirow[t]{2}{*}{ In fields $\alpha$} & \multirow[t]{2}{*}{ Inflow B } & \multicolumn{6}{|c|}{ Outflow Y: Exit } & \multirow{2}{*}{$\begin{array}{c}\text { In fields } \\
\delta \\
\end{array}$} \\
\hline & & & & A & $\mathrm{B}$ & $\mathrm{C}$ & $\mathrm{D}$ & Total & Other $^{* *}$ & & & & & & A & $\mathrm{B}$ & $\mathrm{C}$ & $\mathrm{D}$ & Total & Other & \\
\hline \multirow{4}{*}{ 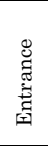 } & $\mathrm{A}$ & \multirow[t]{4}{*}{71} & 148 & - & 1 & 103 & 10 & 114 & \multirow[t]{4}{*}{122} & \multirow[t]{4}{*}{73} & \multirow{4}{*}{ 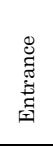 } & $\mathrm{A}$ & \multirow[t]{4}{*}{40} & 127 & - & 0 & 90 & 8 & 98 & \multirow[t]{4}{*}{101} & \multirow[t]{4}{*}{42} \\
\hline & $\mathrm{B}$ & & 139 & 0 & - & 35 & 73 & 108 & & & & $\mathrm{~B}$ & & 96 & 0 & - & 21 & 30 & 51 & & \\
\hline & $\mathrm{C}$ & & 126 & 74 & 21 & - & 1 & 96 & & & & $\mathrm{C}$ & & 84 & 59 & 15 & - & 0 & 74 & & \\
\hline & $\mathrm{D}$ & & 96 & 21 & 45 & 1 & - & 67 & & & & $\mathrm{D}$ & & 43 & 10 & 12 & 2 & - & 24 & & \\
\hline \multicolumn{2}{|c|}{ Total } & 71 & 509 & 95 & 67 & 139 & 84 & 385 & 122 & 73 & \multicolumn{2}{|c|}{ Total } & 40 & 350 & 69 & 27 & 113 & 38 & 247 & 101 & 42 \\
\hline \multirow{2}{*}{\multicolumn{4}{|c|}{$\begin{array}{l}\text { Pedestrian passed density-speed } \\
\text { measurement area }\end{array}$}} & \multicolumn{4}{|c|}{ West to east } & \multicolumn{2}{|c|}{ East to west } & Total & \multirow{2}{*}{\multicolumn{4}{|c|}{$\begin{array}{c}\text { Pedestrian passed density-speed } \\
\text { measurement area }\end{array}$}} & \multicolumn{4}{|c|}{ West to east } & \multicolumn{2}{|c|}{ East to west } & Total \\
\hline & & & & & 10 & 06 & & & 05 & 211 & & & & & & & 93 & & & 79 & 172 \\
\hline
\end{tabular}

\section{Data Analysis}

We compare how the COVID-19 influences pedestrian walking speed and avoidance behaviors. The video clips recorded from 2015 and 2020 can not have precisely the same pedestrian flow conditions to make the comparison. To control the variable, we classify five density levels to compare pedestrian speed and avoidance behavior within the same local density level. We also conducted ANCOVA and ANOVA analysis to exclude the influence of density but focus on the influence of COVID-19.

\section{1 Measured speed in each density level}

In this section, we compare pedestrian speed before and during the pandemic. The samples for speed measuring are selected with the following steps: 1) A snapshot is taken every 30 seconds (enough time for a pedestrian to pass the atrium to avoid sample duplication) from the two main video clips and supplementary video clips; 2) In each snapshot, the pedestrians between entrance/exit $\mathrm{A}$ and $\mathrm{C}$ are assigned ID numbers. 155 pedestrians in 2015 and 140
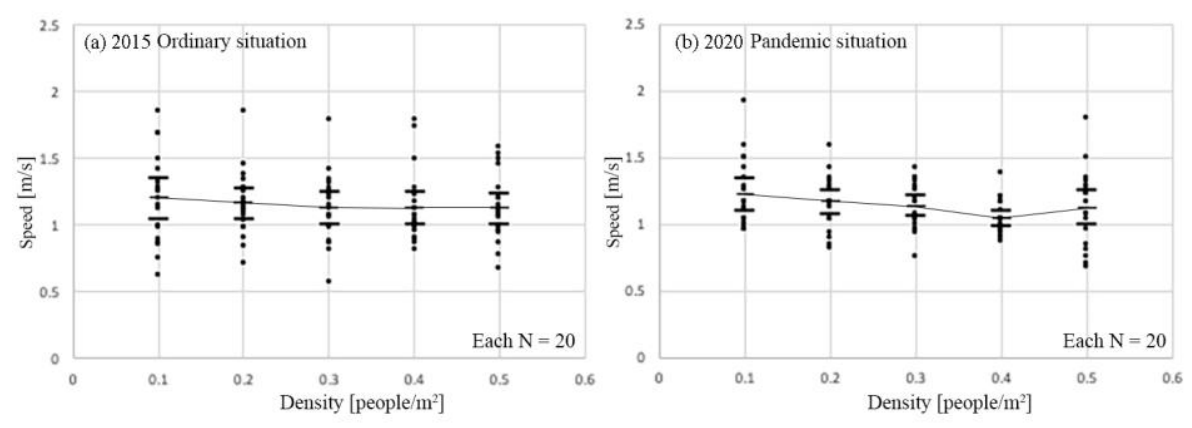

- Measured density-speed pair - Lower or upper limit of $95 \%$ confidence interval - Average of 20 measured values

Fig.3 Measured speed in each density level pedestrians in 2020 are assigned ID numbers; 3) We then go to each ID pedestrian's time frame when his body centerline touches the west/east line of the density-speed measurement area. We count the frames (one frame of video clip = $1 / 30$ second) each pedestrian spends to pass the measurement area. When the pedestrian's body centerline touches the centerline of the measurement area, we count how many other pedestrians are existing in the measurement area. In this way, the density-speed pair for each ID pedestrian is acquired; 4) We classify all the ID pedestrians by their density levels. Steps 2 and 3 are repeated a few times to ensure twenty samples in each density level. Among each density level, ten samples passed the measurement area from west to east inside each density level, and ten samples passed from east to west. In total, 100 samples each from the ordinary situation and the pandemic situation are selected.

Fig. 3 shows all the measured speeds in each density level, the average values, and the $95 \%$ confidence intervals. In the hours the videos were recorded, density above 0.50 people $/ \mathrm{m}^{2}$ is scarce. Therefore, the average speed in the ordinary situation is $1.15 \mathrm{~m} / \mathrm{s}$ with a standard deviation of $0.27 \mathrm{~m} / \mathrm{s}$, while the average speed in the pandemic situation is $1.14 \mathrm{~m} / \mathrm{s}$ with a standard deviation of $0.22 \mathrm{~m} / \mathrm{s}$.

To examine if COVID-19 has influenced pedestrian walking speed, we conducted an analysis of covariance (ANCOVA). ANCOVA evaluates whether the means of a dependent variable (DV) are equal across levels of a categorical independent variable (IV) while statistically controlling for the effects of other continuous variables that are not of primary interest, known as covariates (CV) 22 . All statistic analysis in this paper is conducted using data analysis software SPSS ${ }^{23)}$.

This research analyzes the influence of the COVID-19 (IV) on pedestrian speed (DV). The data set includes two groups, 100 samples in the ordinary situation and 100 samples in the pandemic situation. The pedestrian density is considered in the analysis model as a covariate. This set of data passed the parallelism test that the interactive item: COVID-19*Density does not show significance $(F=0.302, p=0.583>0.05)$. Table2 shows the

Table2 Analysis of covariance on speed

\begin{tabular}{|c|c|c|c|c|c|}
\hline Source of differences & Sum of squares & df & Mean square & $\mathrm{F}$ & $\mathrm{p}$ \\
\hline Intercept & 54.288 & 1 & 54.288 & 922.095 & $0.000^{* * *}$ \\
\hline $\begin{array}{l}\text { COVID-19 } \\
\text { (pandemic/ordinary) }\end{array}$ & 0.008 & 1 & 0.008 & 0.138 & 0.711 \\
\hline Density & 0.247 & 1 & 0.247 & 4.198 & $0.042^{*}$ \\
\hline Density* COVID-19 & 0.018 & 1 & 0.018 & 0.302 & 0.583 \\
\hline Residuals & 11.598 & 197 & 0.059 & & \\
\hline \multicolumn{6}{|l|}{$\mathrm{R}^{2:}: 0.022$} \\
\hline \multicolumn{6}{|c|}{$* \mathrm{p}<0.05 ; * * \mathrm{p}<0.01$} \\
\hline \multicolumn{6}{|c|}{$\begin{array}{l}\text { ANCOVA for the 'measured speed' samples plotted in Fig. } 3 \text {; } \\
\text { Ordinary samples } n=100 \text {, Pandemic samples } n=100 .\end{array}$} \\
\hline
\end{tabular}


results of ANCOVA. The density factor shows significance $(F=4.198, \mathrm{p}=0.042<0.05)$ on its influence on speed, which is an obvious result. However, ANCOVA aims to exclude the influence of density and focus on the influence of COVID-19 on speed. The COVID-19 factor does not show significance $(F=0.138, p=0.711>0.05)$. It means whether or not the pedestrian is walking during the COVID-19 pandemic does not significantly affect pedestrian speed.

5. 2 Personal spacing avoidance (PSA) and long-range avoidance (LRA)

In this section, we compare the avoidance behavior before and during the pandemic. As mentioned before, we define avoidance behavior starting at a distance of less than $3.66 \mathrm{~m}$ as PSA, or else as LRA. Fig.4 shows the illustration of PSA and LRA in the opposite direction. We measure four variables: the avoidance distance and the lateral displacement offset (after this referred to as offset) of avoidance behavior, the encounter number and the avoidance times while a pedestrian transit the atrium. The avoidance distance is the distance from an avoided object when the avoidance subject starts a direction change, and it is marked as L in Fig. $4^{\left.*_{2}\right)}$. The avoidance subject and object's avoidance distance can differ depending on if they start avoidance simultaneously. The offset is the lateral displacement of a subject/object since the avoidance starts and is measured when the distance between the avoidance subject and object is the nearest. The encounter number counts how many other pedestrians one passes by while traversing the atrium. The avoidance times measure how many avoidance behaviors one makes while transiting the atrium.

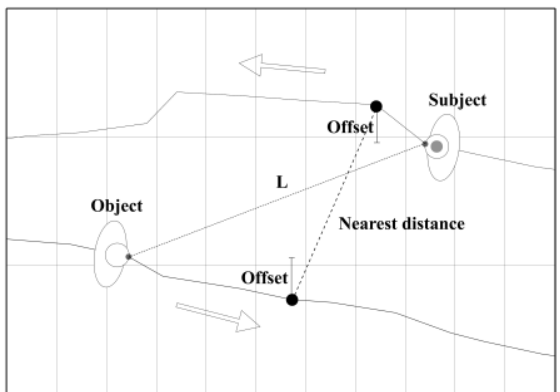

Legend

Subject: the pedestrian starts the avoidance Object: the pedestrian avoided by the subject Walking direction

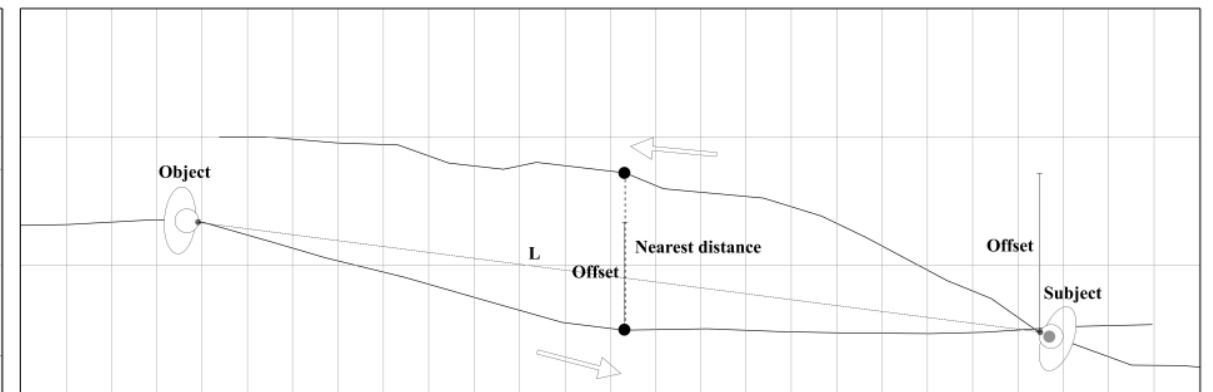

L: the avoidance distance

Offset: the lateral displacement of a pedestrian in the avoidance

when the distance is nearest
- $\bullet$ Nearest distance Pedestrian's walking trajectory

Fig.4 Pedestrian's personal spacing avoidance (PSA) behavior and long-range avoidance (LRA) behavior

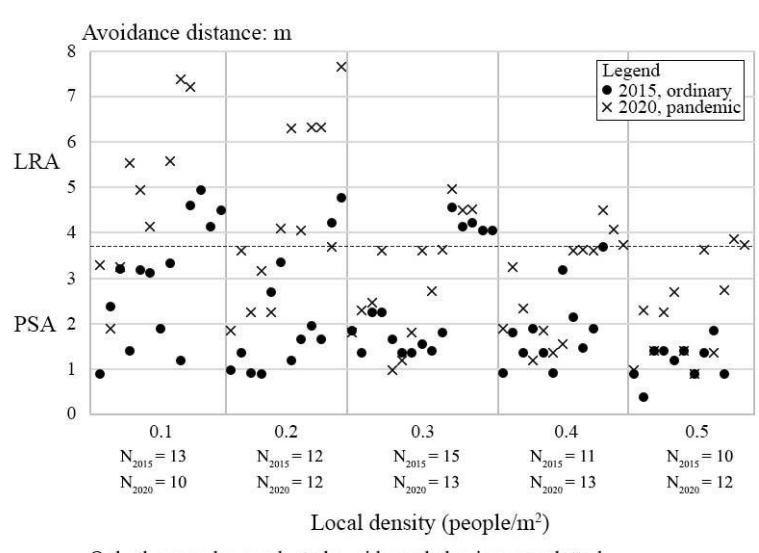

Only the samples conducted avoidance behaviors are plotted.

Fig.5 Pedestrians' avoidance distance in each density level
Table3 Analysis of variance on avoidance distance

\begin{tabular}{|c|c|c|c|c|c|c|c|}
\hline \multicolumn{8}{|c|}{ ANOVA on personal spacing avoidance distance } \\
\hline $\begin{array}{l}\text { Source of } \\
\text { differences }\end{array}$ & \multicolumn{2}{|c|}{ Sum of squares } & df & Mean square & \multicolumn{2}{|c|}{$\mathrm{F}$} & $\mathrm{p}$ \\
\hline Intercept & \multicolumn{2}{|c|}{350.060} & 1 & 350.060 & \multicolumn{2}{|c|}{586.323} & $0.000^{* * *}$ \\
\hline COVID-19 & \multicolumn{2}{|c|}{11.744} & 1 & 11.744 & \multicolumn{2}{|c|}{19.670} & 0.000 *** \\
\hline Density & \multicolumn{2}{|c|}{8.270} & 4 & 2.068 & \multirow{2}{*}{\multicolumn{2}{|c|}{3.463}} & $0.012^{*}$ \\
\hline Residuals & \multicolumn{2}{|c|}{48.360} & 81 & 0.597 & & & \\
\hline \multicolumn{8}{|c|}{$\mathrm{R}^{2}: \quad 0.268 ; * \mathrm{p}<0.05 ; * * \mathrm{p}<0.01$} \\
\hline Density (people/m²) & $0.1(n=12)$ & \multicolumn{2}{|c|}{$0.2(\mathrm{n}=15)$} & $0.3(\mathrm{n}=20)$ & \multicolumn{2}{|c|}{$0.4(\mathrm{n}=20)$} & \multirow{2}{*}{$\begin{array}{l}0.5(n=20) \\
1.17 \pm 0.41\end{array}$} \\
\hline Ordinary & $2.29 \pm 0.97$ & \multicolumn{2}{|c|}{$1.67 \pm 0.81$} & $1.69 \pm 0.35$ & \multicolumn{2}{|c|}{$1.69 \pm 0.66$} & \\
\hline Pandemic & $2.81 \pm 0.80$ & 2.62 & & $2.40 \pm 0.98$ & 2.42 & \pm 0.99 & $.96 \pm 0.89$ \\
\hline \multicolumn{8}{|c|}{ ANOVA on long-range avoidance distance } \\
\hline $\begin{array}{l}\text { Source of } \\
\text { differences }\end{array}$ & \multicolumn{2}{|c|}{ Sum of squares } & $\mathrm{df}$ & \multicolumn{2}{|c|}{ Mean square } & $\mathrm{F}$ & $\mathrm{p}$ \\
\hline Intercept & \multicolumn{2}{|c|}{666.193} & 1 & \multicolumn{2}{|l|}{666.193} & 340.684 & $0.000^{* * *}$ \\
\hline COVID-19 & \multirow{2}{*}{\multicolumn{2}{|c|}{9.150}} & 1 & \multirow{2}{*}{\multicolumn{2}{|c|}{$\begin{array}{l}9.150 \\
2891\end{array}$}} & 4.679 & $0.041^{*}$ \\
\hline Density & & & 2 & & & 1.478 & 0.248 \\
\hline Residuals & \multicolumn{2}{|c|}{46.931} & 24 & \multicolumn{2}{|l|}{1.955} & & \\
\hline \multicolumn{8}{|c|}{$\mathrm{R}^{2}: 0.283 ; * \mathrm{p}<0.05 ; * * \mathrm{p}<0.01$} \\
\hline Density (people/m²) & \multicolumn{2}{|c|}{$0.1(\mathrm{n}=11)$} & \multicolumn{3}{|c|}{$0.2(\mathrm{n}=9)$} & \multicolumn{2}{|c|}{$0.3(\mathrm{n}=8)$} \\
\hline Ordinary & \multirow{2}{*}{\multicolumn{2}{|c|}{$\begin{array}{l}4.54 \pm 0.34 \\
6.51 \pm 2.22\end{array}$}} & \multirow{2}{*}{\multicolumn{3}{|c|}{$\begin{array}{l}4.49 \pm 0.39 \\
5.49 \pm 1.53\end{array}$}} & \multirow{2}{*}{\multicolumn{2}{|c|}{$\begin{array}{l}4.20 \pm 0.21 \\
4.66 \pm 0.26\end{array}$}} \\
\hline Pandemic & & & & & & & \\
\hline
\end{tabular}

The samples selected for the density-speed measurement are continued to use in the avoidance analysis. If one sample has multiple PSA and LRA behaviors in the trip, only the first PSA and LRA are extracted to get a more accurate value among the population. Some pedestrians do not make avoidance during the transit. In total, 61 samples from the ordinary situation and 60 samples from the pandemic situation are selected. Fig.5 shows the avoidance distance distribution in each density level of the selected samples.

Table3 shows using two-way analysis of variance (ANOVA) to study the influences of COVID-19 and density on avoidance distance. PSA and LRA are analyzed separately. In ANOVA for PSA, COVID-19 shows significance ( $\mathrm{F}=19.670, \mathrm{p}=0.000<0.05)$, and it means COVID19 influences the PSA avoidance distance; the density also shows significance $(\mathrm{F}=3.463, \mathrm{p}=0.012<0.05)$, and it means density influences the PSA avoidance distance. In ANOVA for LRA, COVID-19 shows significance $(\mathrm{F}=4.679, \mathrm{p}=0.041<0.05)$, and it means COVID-19 
influences the LRA avoidance distance, while the density does not show significance, means density does not cause a difference in longrange avoidance distance.

Table4 Analysis results of personal spacing avoidance (PSA) behavior and long-range avoidance (LRA) behavior

\begin{tabular}{|c|c|c|c|c|c|c|c|c|c|c|c|c|c|}
\hline \multirow[t]{2}{*}{ Year } & \multirow{2}{*}{\begin{tabular}{|l|} 
Local \\
density \\
(people/m²)
\end{tabular}} & \multicolumn{3}{|c|}{ Personal spacing avoidance (PSA) } & \multicolumn{4}{|c|}{ Long-range avoidance (LRA) } & \multicolumn{2}{|c|}{ Total avoidance times } & \multicolumn{3}{|c|}{ Avoidance rate } \\
\hline & & $\begin{array}{l}\text { Ave. distance }{ }^{* 1} \\
\text { (m) }\end{array}$ & $\begin{array}{l}\text { Ave. offset } \\
\text { (m) }\end{array}$ & $\begin{array}{l}\text { Ave. } \\
\text { times }\end{array}$ & $\begin{array}{l}\text { Ave. distance } \\
(\mathrm{m})\end{array}$ & $\begin{array}{l}\text { Ave. offset } \\
\text { (m) }\end{array}$ & $\begin{array}{l}\text { Ave. } \\
\text { times }\end{array}$ & $\begin{array}{l}\text { Small: large } \\
\text { offset*2 }\end{array}$ & $\begin{array}{l}\begin{array}{l}\text { Ave. encounter } \\
\text { (people) }\end{array} \\
\end{array}$ & $\begin{array}{l}\text { Ave. } \\
\text { times }\end{array}$ & \begin{tabular}{|l} 
Ave. PSA \\
rate*3
\end{tabular} & $\begin{array}{l}\text { Ave. LRA } \\
\text { rate }\end{array}$ & $\begin{array}{l}\text { Ave. total } \\
\text { rate }\end{array}$ \\
\hline \multirow[t]{6}{*}{2015} & 0.10 & 2.29 & 0.50 & 1.90 & 4.54 & 1.37 & 0.40 & $0.50: 0.50$ & 5.50 & 2.30 & 0.35 & 0.07 & 0.42 \\
\hline & 0.20 & 1.67 & 0.44 & 2.40 & 4.49 & 0.20 & 0.30 & $0.00: 1.00$ & 5.30 & 2.70 & 0.45 & 0.06 & 0.51 \\
\hline & 0.30 & 1.69 & 0.41 & 2.10 & 4.20 & 0.78 & 0.50 & $0.60: 0.40$ & 5.60 & 2.60 & 0.38 & 0.09 & 0.47 \\
\hline & 0.40 & 1.69 & 0.51 & 2.70 & 3.68 & 0.59 & 0.20 & $1.00: 0.00$ & 6.30 & 2.90 & 0.43 & 0.03 & 0.46 \\
\hline & 0.50 & 1.17 & 0.35 & 2.80 & - & - & - & - & 7.00 & 2.80 & 0.40 & 0.00 & 0.40 \\
\hline & Average & 1.70 & 0.44 & 2.38 & 4.23 & 0.74 & 0.35 & $0.53: 0.47$ & 5.94 & 2.66 & 0.40 & 0.05 & 0.45 \\
\hline \multirow[t]{6}{*}{2020} & 0.10 & 2.81 & 0.33 & 0.30 & 6.51 & 0.61 & 0.70 & $0.29: 0.71$ & 4.30 & 1.00 & 0.07 & 0.16 & 0.23 \\
\hline & 0.20 & 2.62 & 0.55 & 1.00 & 5.49 & 0.45 & 0.90 & $0.20: 0.80$ & 5.00 & 1.90 & 0.20 & 0.18 & 0.38 \\
\hline & 0.30 & 2.40 & 0.51 & 3.40 & 4.66 & 0.78 & 0.30 & $0.67: 0.33$ & 6.70 & 3.70 & 0.51 & 0.04 & 0.55 \\
\hline & 0.40 & 2.42 & 0.51 & 3.40 & 4.10 & 0.46 & 0.30 & $0.33: 0.67$ & 6.80 & 3.70 & 0.50 & 0.04 & 0.54 \\
\hline & 0.50 & 1.96 & 0.51 & 3.30 & 3.79 & 0.59 & 0.20 & $0.50: 0.50$ & 6.40 & 3.50 & 0.51 & 0.04 & 0.55 \\
\hline & Average & 2.44 & 0.48 & 2.28 & 4.91 & 0.58 & 0.48 & $0.40: 0.60$ & 5.84 & 2.76 & 0.36 & 0.09 & 0.45 \\
\hline
\end{tabular}

Table4 shows the analysis results of PSA and LRA in both situations. In LRA, two types of offset are observed, designated as a small offset when the offset is smaller than $0.40 \mathrm{~m}$ (around one step distance) or else as a large offset. PSA/LRA rate is the number of the PSA/LRA avoidance behavior divided by the total encounter number; it means the frequency one avoids other pedestrians.

PSA and LRA avoidance distance In Table4, we divide the avoidance distance difference by one ladder for $0.40 \mathrm{~m}$, around one walking step. PSA avoidance distance in both ordinary and pandemic situations show three ladders. In the pandemic situation, PSA's average distance is $2.44 \mathrm{~m}$, which is much higher than the average distance of $1.77 \mathrm{~m}$ in the ordinary situation. LRA distance in the ordinary situation shows three ladders, while in the pandemic situation, the distance in each density level varies from the others. In the pandemic situation, the average distance for LRA is $4.91 \mathrm{~m}$, which is much higher than the average distance of $4.23 \mathrm{~m}$ in the ordinary situation. In the ordinary situation, pedestrians stop LRA behavior when the density reaches 0.50 people $/ \mathrm{m}^{2}$.

PSA and LRA offset In the ordinary situation, PSA offset decreases obviously when the density reaches 0.50 people $/ \mathrm{m}^{2}$. In the pandemic situation, the PSA offset stays stable as the density goes higher. The exception at 0.10 people $/ \mathrm{m}^{2}$ is because pedestrians take longer LRA avoidance distance. Also, because of the longer LRA avoidance distance under the pandemic situation, the average LRA offset of $0.74 \mathrm{~m}$ in the ordinary situation is larger than $0.58 \mathrm{~m}$ in the pandemic. In the ordinary situation, 0.47 of the LRA takes a larger offset, while in the pandemic situation, this number increases to 0.60 .

PSA and LRA rate The average total avoidance rate of PSA and LRA keeps unchanged at 0.45 . However, in the pandemic situation, the rate of LRA behavior increases from 0.05 to 0.09 .

Big gestures (BG) When a pedestrian can not make avoidance in advance, the pedestrian starts and finishes the avoidance in one or two walking steps. We found big gesture avoidance behaviors quite often in the videos. The observed BG includes: 1) A pedestrian encounters with a few other pedestrians side by side; 2) A fast-walking pedestrian wants to pass a slow walking pedestrian in front of him; 3) Crossing pedestrians choosing conflicting walking directions.

Conclusions of comparative analysis The analysis results show that under the pandemic conditions: 1) Pedestrian walking speed does not have significant changes; 2) Pedestrians have significant longer avoidance distance; 3) The lateral displacement offset of avoidance behavior is slightly higher in PSA; 4) Pedestrians conduct LRA more often. Also, pedestrians will conduct sudden avoidance when they realize they are too close to one another (BG). These findings are thought to reflect pedestrian's 'distancing' awareness.

\section{Modeling Approach: Agent Simulator of Contagious Pedestrian Proximity}

\section{1 Simulation platform and spatial expression}

Our Agent Simulator of Contagious Pedestrian Proximity (ASCPP) is built on a multi-agent modeling platform, artisoc, based on the framework of ASPF pedestrian walking simulator 24) 25) 26). Different agents can exist and interact with each other according to their rules under the variable settings. In the ASCPP, the space layout is located in an absolute cell-space coordinate system, while each agent has its own relative cell-space coordinate system. This type of hybrid cell space makes the agent walk in any direction without the restriction of the cell grids ${ }^{25)}$, 26), 27).

\section{2 Model algorithm}

Fig. 6 shows the pedestrian agent's algorithm. A pedestrian agent is generated according to the setup generation rate and origin-destination matrix at its entrance. The agent's trip towards its destination moves following the shortest path principle on our preset waypoints while 
avoiding other agents and obstacles. The waypoints are temporary targets while walking towards the destination exit and are set based on the directly visible principle. When an agent moves into the sphere of its target, it updates its target. The waypoint and the sphere around it are set up intuitively according to observation and simulation test run. The waypoint network and the sphere of each waypoint are shown in Fig.10. The agent will confirm its direction towards the target every three steps. In each step, the pedestrian agent will scan agents in the close-by cells and apply normal density avoidance rules. If there are not agents in the close-by cells, the agent will continue to scan its personal space and long-range space to apply low-density avoidance rules. This algorithm repeats every simulation step until the agent reaches its destination.

Each simulation runs for 2700 steps.

\section{3 Absolute and relative coordinate system}

Fig. 7 shows the illustration of the coordinate systems utilized in our simulation model adopted from the ASPF pedestrian walking simulator ${ }^{25)}$ 26). The time scale is set at three steps per second which is similar to the actual situation of the videos above.

The cell is set 40 by $40 \mathrm{~cm}$ square in the absolute coordinate system to get an essential setting for the average speed (around $1.2 \mathrm{~m} / \mathrm{s}$ ). The absolute coordinate system is a system with two decimal places real numbers, and it reflects the simulation map layout that can be observed directly from the simulation interface. The true north direction of the map is set to $0^{\circ}$ on the Y-axis in the absolute coordinate system.

In the relative coordinate system, the cell size is decided by each agent's step size that makes the agent able to have different speeds. The Y-axis direction follows the agent's current direction. The agent avoids others following the ASCPP rulesets in the relative coordinate system. The decimal places are dropped to adapt to the behavior rules to know the avoidance direction. The avoidance probability for each rule follows the avoidance rate in Table4. Because the agent encounters other agents from different directions, the agent can deviate from the original direction for a short time and walk without the cells' limitation in the absolute coordinate system.

\section{4 ASCPP rulesets}

Fig. 8 shows the ASCPP rulesets. The bold frame denotes the vision of the agent. The shaded cell means this cell needs to judge that another agent does not exist. The merged cells mean

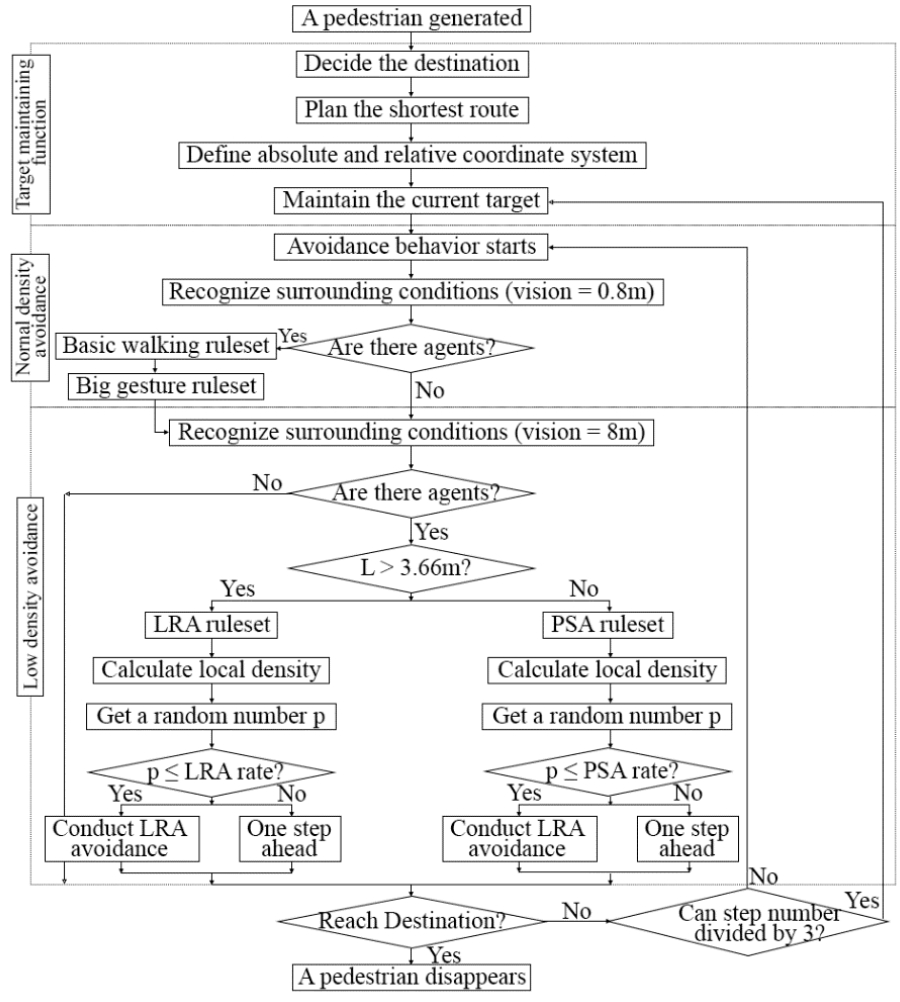

Fig.6 Pedestrian agent's algorithm

Decimal places are dropped in the relative coordinate system to adapt behavior rules

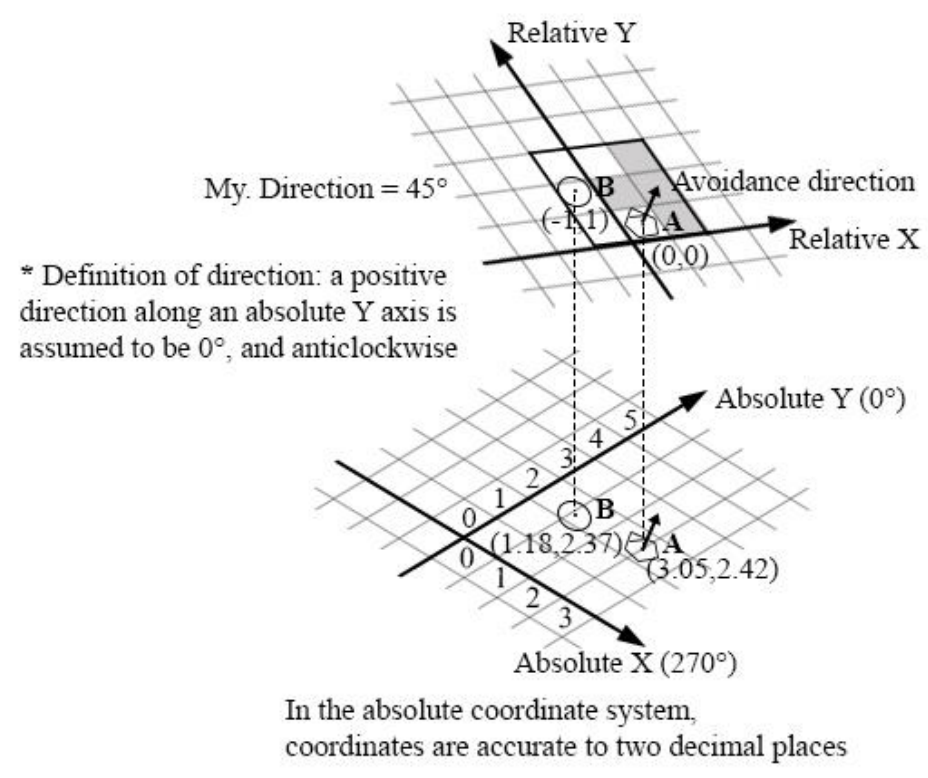

Fig.7 Illustration of the relative coordinate system adopted from ASPF pedestrian agent model by Kaneda and Okayama, $2007^{25}$ the existence of other agents in any of those cells is equal. The left-right inverted states are omitted. We know from the video analysis that some pedestrian avoidance takes more than one step to finish when the offset is large. The step number reflects the simulation steps need to finish the avoidance. ASCPP includes four behavioral rulesets extracted from the video analysis results: 8 basic behavior rules for the ordinary case and 7 basic behavior rules for the pandemic case, 1 big gesture rule, 2 long-range avoidance rules, and 6 personal spacing avoidance rules. Each agent selects only one rule from the ASCPP rulesets in each simulation step by the sequential order of rule number, according to its surroundings. The updating of each agent's movement inside one simulation step is random sequential. The right/left turn 
in a rule is random with 50:50. The PSA and LRA avoidance follow the extracted avoidance rate and avoidance distance according to the local density level in Table4. The offset of LRA behavior also has a probability of being a large or small offset.

\section{5 Pedestrian proximity zones}

Table5 and Fig.9 show the proximity zones developed based on the relevant studies examined in section 2. Pedestrian looking direction is the same as the walking direction. Pedestrian proximity zones extend 90 degrees left and right from the looking direction. Before judging proximity zones, the encountering pedestrians' direction difference will be calculated to ensure only face-toface encounters are included.

A contagious agent is visualized with the color red. An agent in Zone A is visualized with the color cyan, which means it is exposed to a sneezing contagious agent when neither of them is wearing a mask. An agent in Zone B is visualized with the color blue, which means it is exposed to a heavy cough contagious agent when neither of them is wearing a mask. An agent in Zone $\mathrm{C}$ is visualized with the color yellow, which means it is exposed to an average cough contagious agent when neither of them is wearing a mask. An agent in Zone D is visualized with the color magenta, which means it is exposed to a contagious agent even though both are wearing masks. The agents out of all the above zones are in the exposure-free zone and visualized with green color. An agent's proximity zone can only be upgraded to a higher proximity zone. Each agent is only calculated once in its highest proximity zone as one of the simulation outputs.

\section{6 Variable settings}

Our simulator includes three variable categories: the general variables, pedestrian variables, and input variables. The general variables include variables for the generators, origin-destination settings, waypoint settings, proximity zone settings, and different counters. The pedestrian variables, including the coordinate systems, direction, speed, destination, target, health, encounter, and mask-wearing condition. The input variables, including pedestrian generation rate for each entrance, the contagious rate among the population, the mask-wearing rate among the population, the avoidance distance for each density level (PSA and LRA), PSA and LRA rate.

The speed of each agent is set from our video analysis results: in the ordinary situation, the average speed $1.15 \mathrm{~m} / \mathrm{s}$ and the standard deviation $0.27 \mathrm{~m} / \mathrm{s}$ with normal distribution, while in the pandemic situation, the average speed is $1.14 \mathrm{~m} / \mathrm{s}$ and the standard deviation $0.22 \mathrm{~m} / \mathrm{s}$ with normal distribution.
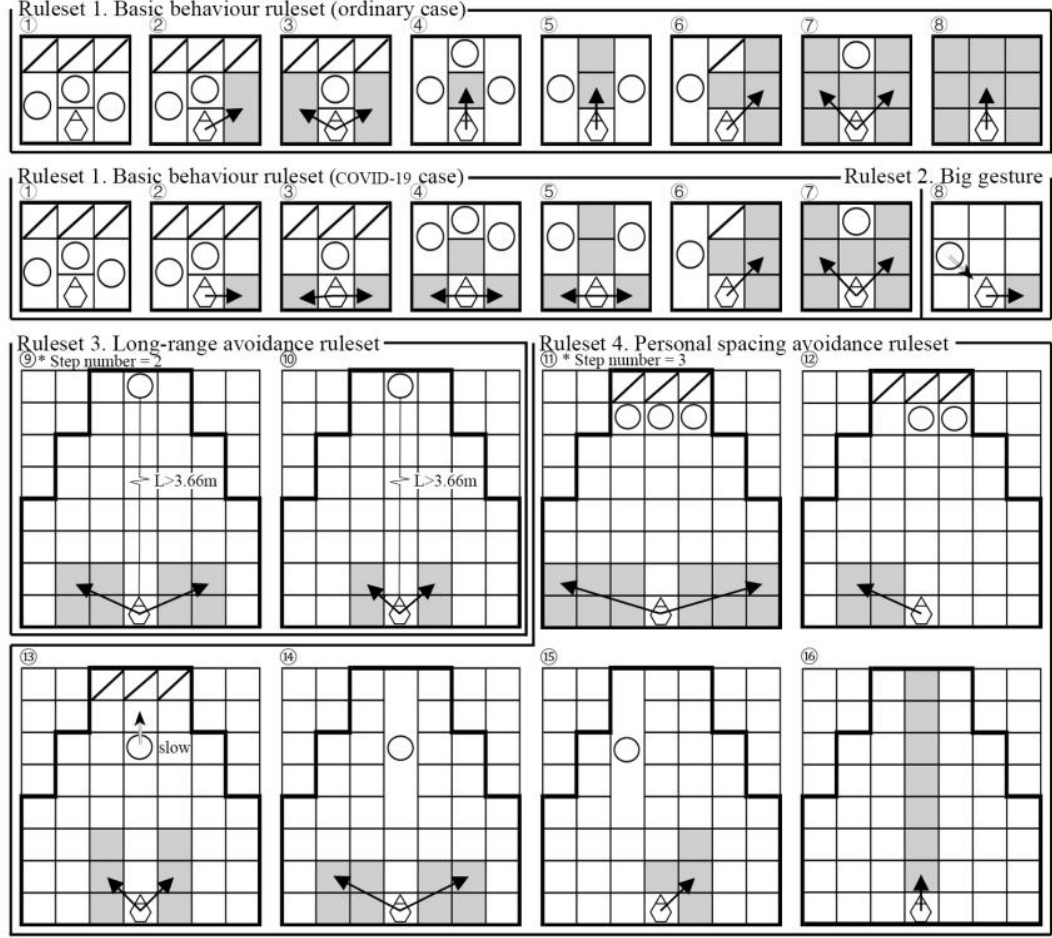

A My agent (The triangle indicates the current direction) 4 Agent's movement in relative coordinate system Other agent

$\uparrow$ Another agent's current walking direction

The cell needs to judge other agent does not exist $\square$ The cell does not need to judge

* Step number: the simulation steps required to achieve the avoidance (default as 1)

* The left-right inverted states are omitted

Fig.8 ASCPP pedestrian behavior rulesets

Table5 Pedestrian proximity zones

\begin{tabular}{lllllc}
\hline $\begin{array}{l}\text { Proximity } \\
\text { zone }\end{array}$ & Description & $\begin{array}{l}\text { Influence } \\
\text { distance }\end{array}$ & $\begin{array}{l}\text { Mask full } \\
\text { protection }\end{array}$ & Reference & $\begin{array}{l}\text { Visualized } \\
\text { color }\end{array}$ \\
\hline $\mathrm{A}$ & $\begin{array}{l}\text { A multiple turbulent gas cloud can reach } \\
\text { when sneezing with face uncovered. }\end{array}$ & & & Cyan \\
\hline $\mathrm{B}$ & $\begin{array}{l}\text { A heavy cough jet can reach with face } \\
\text { uncovered. }\end{array}$ & $3.66 \mathrm{~m}$ & 0 & $4)$ & Blue \\
\hline $\mathrm{C}$ & $\begin{array}{l}\text { Average cough jet distance with face } \\
\text { uncovered. }\end{array}$ & $2.44 \mathrm{~m}$ & 0 & $4)$ & Yellow \\
\hline $\mathrm{D}$ & $\begin{array}{l}\text { Average air leak can reach even wearing a } \\
\text { non-woven mask. }\end{array}$ & & & Magenta \\
\hline
\end{tabular}

Table6 Model validation results

\begin{tabular}{l|c|c|c|c|c|c|c|c|c|c}
\hline & \multicolumn{4}{|c|}{ Ordinary case (2015) } & \multicolumn{4}{c}{ Pandemic case (2020) } \\
\cline { 2 - 12 } & $\begin{array}{c}\text { PSA } \\
\text { times }\end{array}$ & $\begin{array}{c}\text { LRA } \\
\text { times }\end{array}$ & $\begin{array}{c}\text { Ave. } \\
\text { Encounter } \\
\text { (people) }\end{array}$ & $\begin{array}{c}\text { PSA } \\
\text { rate }\end{array}$ & $\begin{array}{c}\text { LRA } \\
\text { rate }\end{array}$ & $\begin{array}{c}\text { PSA } \\
\text { times }\end{array}$ & $\begin{array}{c}\text { LRA } \\
\text { times }\end{array}$ & $\begin{array}{c}\text { Ave. } \\
\text { Encounter } \\
\text { (people) }\end{array}$ & $\begin{array}{c}\text { PSA } \\
\text { rate }\end{array}$ & $\begin{array}{l}\text { LRA } \\
\text { rate }\end{array}$ \\
\hline Ave. measured value $^{* 1}$ & 2.70 & 0.20 & 6.30 & 0.43 & 0.03 & 3.40 & 0.30 & 6.80 & 0.50 & 0.04 \\
\hline Ave. simulation value*2 & 2.25 & 0.58 & 6.38 & 0.35 & 0.09 & 2.67 & 0.28 & 4.78 & 0.55 & 0.06 \\
\hline Error & -0.45 & 0.38 & 0.08 & -0.08 & 0.06 & -0.73 & -0.02 & -2.02 & 0.05 & 0.02 \\
\hline
\end{tabular}

*1 The survey video analysis data from Table 4 , in the density level 0.4 people $/ \mathrm{m}^{2}$

$*_{2}$ Each average value is the results of 20 simulation runs; the average local density of 20 simulation runs is in the density level of 0.4 agent $/ \mathrm{m}^{2}$. 


\section{7 Model validation}

As a validation of the model, we ran 20 simulation trials with an average local density of 0.4 people $/ \mathrm{m}^{2}$ for both ordinary case and pandemic case. From the output of the trials, we calculated PSA and LRA rates by dividing the values of PSA and LRA times by Average Encounter. Table6 shows the comparison with the measured values with the same density level in Table4. The PSA rate was found to have an error of -0.08 (measured value 0.43 , simulation value 0.35 ) for the ordinary case and 0.05 (measured value 0.50 , simulation value 0.55 ) for the pandemic case. On the other hand, the error in the LRA rates was found to be 0.06 (measured 0.03, simulation 0.09) for the ordinary case and 0.02 (measured 0.04, simulation 0.06) for the pandemic case. The simulation outputs relatively well-reproduced pedestrian survey data. This validation result shows that the model can reproduce the PSA and LRA behaviors and make further predictions.

\section{Simulation Scenario Design}

Table7 shows the simulation scenario design. In total, five scenarios are considered. These scenarios range from the ordinary case without the mask-wearing population (Sc.000) to the pandemic case with the different mask-wearing population (Sc.100Sc.120) and the pandemic case with standing pedestrians (Sc.101). Sc.120 reflects the actual pedestrian flowrate and mask-wearing rate, as in the 2020 video.

In Sc.101, two standing agents are located in the pedestrian flow between entrance/exit A and C. The golden clock atrium is a customary waiting area for pedestrians in Nagoya Station. While most waiting pedestrians are standing by the walls or the escalator, a few standing pedestrians are often present on other pedestrians' walking paths.

In each scenario, $1 \%$ of the population is set as contagious and does not wear masks. This is a hypothetical condition to show the influence of each influential factor. Under different flowrate settings, the total population vary from around 1500 to $2100.1 \%$ is a value decided from the simulation test run to ensure there is no more than one contagious agent on the map simultaneously, and the contagious agents occupy the same proportion of the total population. The contagious agents appear on the map at even time intervals and travel from entrance/exit A to C. Each scenario was run 20 times in the video taken flowrates from 2015 and 2020 to reduce the error caused by different pedestrian flowrate. At the end of each simulation run, the number of agents in each proximity zone is divided by the total population to get a proximity zone rate.

\section{Simulation Results And Discussion}

This section presents the application of our ASCPP model to estimate the pedestrian proximity probability with a contagious agent. According to the survey videos, the densities in all the scenarios are lower than 0.5 people/m2. Fig.10 shows the simulation snapshots. Table8 shows the simulation results of the agent distribution in each proximity zone. Fig.11 shows the agent number in each proximity zone with the means and 95\% confidence intervals. After plotting the above data, we can compare the relationships across scenarios with the spans of the confidence intervals based on 20 times simulation runs.

8. 1 Influence of pedestrians' 'distancing' awareness Comparing Sc.000 and Sc.100 reveals the influence of pedestrians' 'distancing' awareness during the COVID-19 pandemic. The t-test results in Table9 show that the numbers of agents in proximity Zone $\mathrm{C}$ and $\mathrm{D}$ are significantly different. This result shows that pedestrians' 'distancing' awareness influences pedestrian exposure within the range of proximity Zone $\mathrm{C}$.

\section{2 Influence of mask-wearing population}

Comparing Sc.100 with Sc.110, Sc.120 reveals the

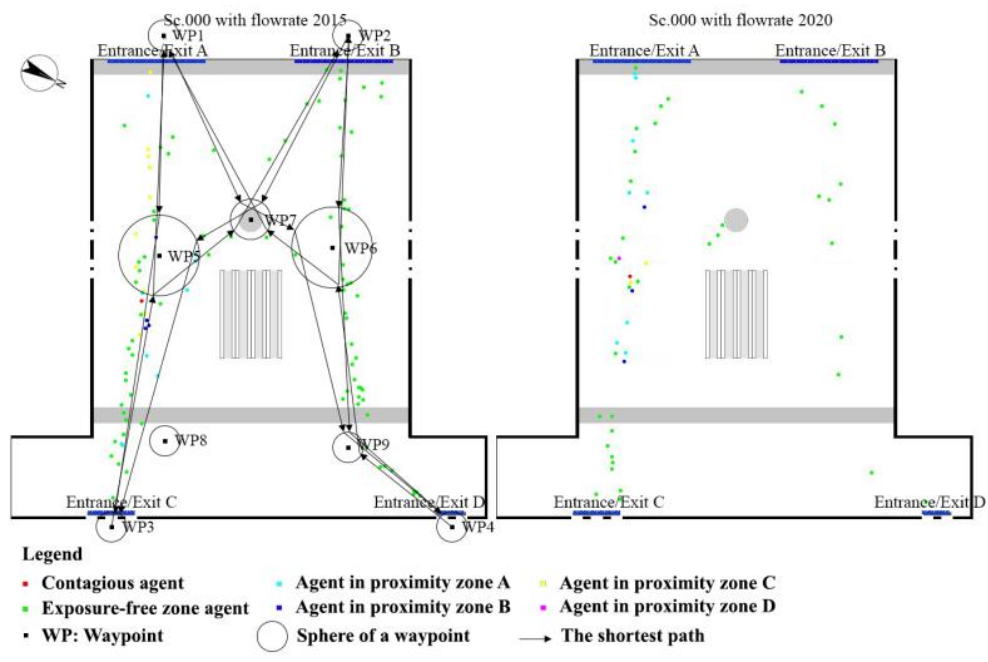

Fig.10 Waypoint network and simulation snapshot

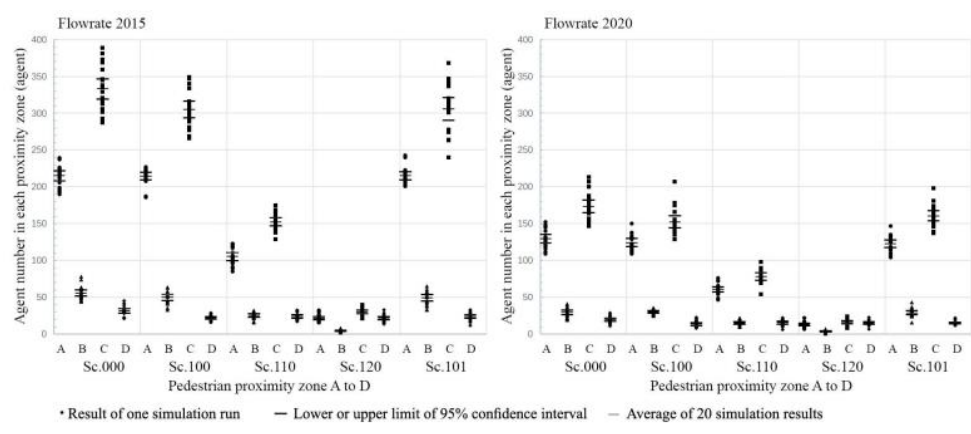

Fig.11 Agent number in each proximity zone 
influence of the mask-wearing population, with a ladder of $0 \%, 50 \%$, and $90 \%$. In the flowrate for 2015 , the exposure-free agents increased by $13.50 \%$ and $24.42 \%$, respectively. In the flowrate for 2020 , the exposure-free agents increased by $9.93 \%$ and $18.02 \%$. Because wearing a non-woven mask cannot protect from air leak in proximity Zone $\mathrm{D}$, the increase of exposure-free agents is non-linear. Pedestrians' personal spacing avoidance behavior mainly happens in the $2.44 \mathrm{~m}$ range of Zone C. The mask-wearing ratio among the population affects the number of agents in Zone $\mathrm{C}$ directly. In flowrate 2015 , the agents in proximity Zone $\mathrm{C}$ reduced by $7.76 \%$ and $5.83 \%$ respectively, and in flowrate 2020 , the agents in proximity Zone C reduced by $4.90 \%$ and $4.12 \%$. In both flowrate 2015 and 2020, the agents in proximity Zone D change minorly. This result shows that the mask-wearing population has an influence on pedestrian proximity probability.

\section{3 Influence of standing pedestrians}

Comparing Sc.100 and Sc.101 reveals the influence of standing agents on proximity probability. In flowrates 2015 and 2020, the exposurefree agents reduced by $0.14 \%$ and $0.76 \%$. This result shows that standing pedestrians influence proximity probability to a minor degree.

\section{4 Violation of physical distancing with a contagious person}

Zone $\mathrm{C}$ and Zone $\mathrm{D}$ together have a range of $2.44 \mathrm{~m}$, which covers a loose range of physical distancing. Comparing the results of Sc.000 and Sc.100 of flowrate 2020 shows that by improving pedestrians' 'distancing' awareness, the violation of physical distancing with a contagious agent can be reduced by $1.67 \%$. Comparing the results of Sc.100, Sc.110, and Sc.120 of flowrate 2020 shows that, by encouraging $90 \%$ of the population to wear a face mask, the exposure within the physical distancing to a contagious agent can be reduced by $8.89 \%$. Comparing the results of Sc.000 and Sc.101 of flowrate 2020 shows that by removing the standing pedestrians, the violation of physical distancing with a contagious agent can be reduced by $0.85 \%$.

\section{Conclusions}

This study aimed to develop an ABM tool for estimating pedestrian proximity probability in public space and explore an agent-based modeling and simulation framework for emergency space planners and designers.

We first analyzed pedestrian walking behavior before and during the COVID-19 pandemic from video clips recorded in 2015 and 2020. The analysis results show that under the influence of COVID-19 pandemic: 1) Pedestrian walking speed does not show the difference; 2) Pedestrians have significant longer avoidance distance; 3) The lateral displacement offset of avoidance behavior is slightly higher in PSA; 4) Pedestrians conduct LRA more often. These findings are thought to reflect pedestrian's 'distancing' awareness.

Based on the above analysis results, an ABM, ASCPP, was developed to model pedestrian behavior in ordinary and pandemic situations. This model included four rulesets, 16 rules in total, and validated by reproducing PSA and LRA rates with the video analysis results in ordinary and pandemic situations. Then simulations were conducted for five scenarios under both situations considering the presence/absence of 'distancing' awareness, the different face-mask wearing rate, and the obstruction of flows by people standing still. In each scenario, the average probability of pedestrian proximity was estimated. The simulation results show that: 1) T-tests have been conducted for the presence/absence of the 'distancing' awareness, and significant differences were confirmed; 2) The influential factors affect pedestrian proximity probability with a contagious agent in the sequential order of face-mask wearing rate, 'distancing' awareness, and the presence of standing pedestrians; 3) Quantitively estimated the violation of physical distancing with a contagious pedestrian in a hypothetical scenario in a facility-level space as a tool to help future policymaking.

Under the worldwide pandemic, the need to reduce physical contact in public spaces is increasing. Through this study, we have gained the prospect to develop a feasible methodological framework for pedestrian agent modeling and simulation that is consistent with the data survey to contribute to spatial considerations during the pandemic. The future challenge concerns larger-scale data collection in commuting hours and different space types. 


\section{Reference}

1) Kissler, S. M., Tedijanto, C. and Goldstein, E., et al.: Projecting the Transmission Dynamics of SARS-CoV-2 Through the Postpandemic Period, Science, Vol. 368, No. 6493, pp. 860-868, 2020. 5

2) Singhal, T.: A Review of Coronavirus Disease-2019 (COVID-19), The Indian Journal of Pediatrics, Vol. 87, No. 4, pp. 281-286, 2020. 3

3) Bourouiba, L.: Turbulent Gas Clouds and Respiratory Pathogen Emissions - Potential Implications for Reducing Transmission of COVID-19, JAMA, Vol. 323, No. 18, pp. 1837-1838, 2020. 3

4) Verma, S., Dhanak, M. and Frankenfield, J.: Visualising the Effectiveness of Face Masks in Obstructing Respiratory Jets, Physics of Fluids, Vol. 32, No. 6, 2020. 6

5) D'Orazio, M., Bernardini, G. and Quagliarini, E.: Sustainable and Resilient Strategies for Touristic Cities Against COVID-19: An Agent-Based Approach, arXiv:2005.12547 [physics.soc-ph], Unpublished, Accessed February 26, 2021

6) Fang, Z., Huang, Z. and Li, X. et al.: How Many Infections of COVID-19 There Will Be in the 'Diamond Princess' - Predicted by a Virus Transmission Model Based on the Simulation of Crowd Flow, arXiv:2002.10616 [physics.soc-ph], Unpublished, Accessed February 26, 2021

7) Mahmood, I., Arabnejad, H. and Suleimenova, D., et al.: FACS: A Geospatial Agent-Based Simulator for Analysing COVID-19 Spread and Public Health Measures on Local Regions, Journal of Simulation, doi: 10.1080/17477778.2020.1800422, 2020. 8

8) Cuevas, E.: An Agent-Based Model to Evaluate the COVID-19 Transmission Risks in Facilities, Computers in Biology and Medicine, Vol. 121, 103827, 2020. 5

9) D’Orazio, M., Bernardini, G. and Quagliarini, E.: How to Restart? An Agent-Based Simulation Model Towards the Definition of Strategies for COVID-19' Second Phase' in Public Buildings, arXiv:2004.12927 [physics.soc-ph], Unpublished, Accessed February 26, 2021

10) Müller, S. A., Balmer, M. and Charlton, W., et al.: A Realistic Agent-Based Simulation Model for COVID-19 Based on a Traffic Simulation and Mobile Phone Data, arXiv:2011.11453 [physics.soc-ph], Unpublished, Accessed February 26, 2021

11) Coronavirus Disease (COVID-19) Advice for the Public, World Health Organization, Last updated February 24, 2021, Accessed February 26, 2021, https://www.who.int/emergencies/diseases/novel-coronavirus-2019/advice-for-public

12) Travelers From Countries with Widespread Sustained (ongoing) Transmission Arriving in the United States, Centers for Disease Control and Prevention, Last updated February 18, 2021, Accessed February 26, 2021, https://www.cdc.gov/coronavirus/2019-ncov/travelers/after-travel-precautions.html 13) Ministry of Health, Labour and Welfare, Information on Health and Medical Consultation, Accessed February 26, 2021,

https://www.mhlw.go.jp/stf/covid-19/kenkou-iryousoudan_00006.html

14) Hall, E. T.: The Hidden Dimension, Anchor Books, 1966

15) Fruin, J. J.: Pedestrian Planning and Design, New York: Metropolitan Association of Urban Designers and Environmental Planners, Inc., 1971

16) Golas, A., Narain, R., Curtis, S. and Lin, M.: Hybrid Long-Range Collision Avoidance for Crowd Simulation, IEEE Transactions on Visualisation and Computer Graphics, Vol. 20, No. 7, 2013. 9

17) Tatebe, K. and Nakajima, H.: Avoidance Behavior Against a Stationary Obstacle under Single Walking: A Study on Pedestrian Behavior of Avoiding Obstacles (I), Journal of Architecture, Planning and Environmental Engineering (Transactions of AIJ), No. 418, pp. 51-57, 1990. 12 (in Japanese) 建部謙治, 中島一：静止した障害物に対する単独歩行者の回避行動：歩行者の回避行動に関する研究(I), 日本建築学会計画系論文報告集, 第 418 号, pp. $51-57$, 1990. 12

18) Tatebe, K., Tsujimoto, M. and Shida, K.: Methods for Judging the Beginning Point of Avoiding Behavior and Avoidance Distance between A Pedestrian and a Standing Obstacle: A Study on Pedestrian Behavior of Avoiding Obstacles (II), Journal of Architecture and Planning (Transactions of AIJ), Vol. 59, No. 465, pp. 95-104, 1994. 11 (in Japanese)

建部謙治, 辻本誠, 志田弘二：回避行動開始点の判定と前方回避距離：歩行者の回避行動に関する研究(II), 日本建築学会計画系論文集, 第 59 巻, 第 465 号, pp. 95-104, 1994. 11

19) Tang, S., Kwak, D. and Kitahara, T.: A Study of a Distance Modle of People-To-People Avoiding Behavior in a Station Square: Correlative Factors of PeopleTo-People Avoidance Behavior Distance, Journal of Architecture and Planning (Transactions of AIJ), Vol. 77, No. 679, pp. 2101-2107, 2012. 9

20) Tang, S., Kwak, D. and Kitahara, T.: A Study of Pedestrian Personal Space in a Station Square: People-To-People Avoidance Behavior in Nishi-Chiba Station Square, Journal of Architecture and Planning (Transactions of AIJ), Vol. 77, No. 681, pp. 2569-2575, 2012.11

21) Mizuno, T., Shohmitsu, M. and Kaneda, T.: A Study on the Agent-Simulation of Waiting Behaviours Inside a Transfer Station Space, 2016 IEEE 40th

Annual Computer Software and Applications Conference (COMPSAC), Vol. 2, pp. 111-116, 2016. 8

22) Keppel, G.: Design and Analysis: A Researcher's Handbook (3 ${ }^{\text {rd }}$ ed.), Englewood Cliffs: Prentice-Hall, Inc., 1991

23) SPSSAU, QingSi Technology Ltd., Accessed September 9, 2020, https://spssau.com/en/index.html

24) Artisoc, Kozo Keikaku Engineering Inc., Accessed February 26, 2021, https://www.kke.co.jp/solution/theme/artisoc.html

25) Kaneda, T. and Okayama, D.: A Pedestrian Agent Model Using Relative Coordinate Systems, In: Terano, T., Kita, H., Deguchi, H. and Kijima, K. (eds)

Agent-Based Approaches in Economic and Social Complex Systems IV. Agent-Based Social Systems, Vol. 3, Springer, Tokyo, 2007.12

26) Kaneda, T., Yoshida, T., He, Y., Tamada, M. and Kitakami, Y.: Adding Higher Intelligent Functions to Pedestrian Agent Model, In: Klingsch, W., Rogsch, C., Schadschneider, A. and Schreckenberg, M. (eds) Pedestrian and Evacuation Dynamics 2008, Springer, Berlin, Heidelberg, 2009.12

27) Shohmitsu, M. and Kaneda, T.: Simulation Analyses on Phase Transition in Counter Flow Situations by Using a Pedestrian Agent Model with Simplified Behavior Rules, AIJ Journal of Technology and Design, Vol. 23, No. 54, pp. 721-724, 2017. 6 (in Japanese)

正光将大, 兼田敏之：行動ルールを用いた歩行者エージェントモデルによる対向流の相転移の分析, 日本建築学会技術報告集, 第 23 巻, 第 54 号, pp. $721-724$, 2017. 6

Notes

*1) This research is sponsored by the China Scholarship Council, identification number: 201806260268 and Japan Society for the Promotion of Science, KAKENHI Grant Number: 18H03825.

*2) Direction change: A direction change means a continuous change in the direction of travel from one to several steps. If the direction of a pedestrian at walking step $\mathrm{n}$ is represented by a vector consisting of position $\mathrm{Pn}$ at the time and position $\mathrm{Pn}-1$ one step before, the avoidance starting point is the first point where the angle of direction change exceeds 10 degrees. 
Summary in Japanese

COVID-19 が世界的パンデミックとなり、公共空間においてフィジカル・ディスタンシングが推奨されるようになった。歩行者のための屋内 空間利用の計画基準はパンデミック前におけるものであるため、公共空間における歩行者の近接確率を考慮した定量的な研究はこれまで見られ なかった。このような状況においては歩行者行動の動的特性を考慮したエージェント・ベースド・モデリング (ABM) が有望である。本研究の 目的は、駅構内アトリウムにおける歩行者の近接確率を推計するためのエージェントベースの歩行者シミュレーションツールを開発し、緊急時 の空間プランナーやデザイナーのためのエージェント指向のモデリングとシミュレーションの枠組みを模索することである。

まず、COVID-19 パンデミックの一般的な特徴、世界的なフィジカル・ディスタンシングの政策や勧告、屋内公共空間における密度制御の分 野での ABM の応用など関連する研究をレビュウするとともに、これらの研究から近接レベル A から D までの歩行者近接ゾーンを設定した。

次に、パンデミック時の 2020 年 6 月に名古屋駅構内アトリウムにおいて平日の非通勤時間帯に撮影した低密状況における歩行者の回避行動 について、平常時の 2015 年に同じ場所で実施したビデオ映像との比較分析を行った。その結果、各密度水準とも両時点の歩行速度の平均值に は違いはみられないものの、パンデミック時の歩行者の回避行動は通常時に比べて開始距離の平均值が長いこと（分散分析において有意差）が 明らかになり、これは人びとのディスタンシング意識が反映したものと考えられる。これらの考察より、本研究では回避行動を回避開始距離 $3.66 \mathrm{~m}$ を閾值としてPSA（パーソナル・スペーシングによる回避行動）と LRA（長距離回避行動）の 2 つに分割して 1 軌跡あたりの発生回数、 すれ違い時回避幅などを分析した。

以上の分析結果を踏まえ、平常時・パンデミック時の双方の時点における歩行者行動を扱うために開発したASCPPは、ASPFを土台としな がら 16 コの行動ルールを有するものである。モデルの妥当性検討として両時点における PSA、LRAの発生回数などの再現を検討した。次い で、ディスタンシング意識の有無、マスク着用の有無、立止り者の存在による流れの阻害を扱う5つのシナリオによる駅構内の対向流のシミュ レーションを実施し、歩行者集団の中での感染者 $1 \%$ 条件における近接確率のシナリオごと影響を検討した。また、あわせて動的な歩行状況で はどの程度間隔を保持できない可能性が高いのか、という点に着目して考察した。とくにディスタンシング意識の有無について $\mathrm{t}$ 検定を行い、 有意差を確認している。

結論では一連の作業より得られた知見を要約した。一連の作業を通じて、パンデミック時における空間検討に資するためにデータ調査と整合 性を有した歩行者エージェントモデリングとシミュレーションの方法論的枠組みが実現可能であるという見通しを得ることができたことが本 研究の収穫と言える。より規模の大きなデータ採取を通じての一般性の高い方法論的枠組みを模索することが今後の課題である。

\section{Summary in English}

With the global pandemic of COVID-19, physical distancing has become a recommended practice in public spaces. Since the planning standards for indoor space use are based on pre-pandemic situations, there are no quantitative studies considering the pedestrian proximity probability in public spaces. With this background, agent-based modeling (ABM) that takes into account the dynamic characteristics of pedestrian behavior is promising. This study aims to develop an ABM tool for estimating pedestrian proximity probability in a station atrium and explore an agent-based modeling and simulation framework for emergency space planners and designers.

First, we reviewed relevant studies on the general characteristics of the COVID-19 pandemic, global physical distancing policies and recommendations, and the application of ABM in the field of density control in indoor public spaces and established pedestrian proximity zones from proximity levels A to D from these studies.

Next, we conducted a comparative analysis of pedestrian avoidance behavior in low-density conditions filmed during non-commuting hours on weekdays in the atrium of Nagoya Station in June 2020 during the pandemic, with video footage taken in the same location in 2015 during the ordinary period. As a result, even the pedestrian walking speed at both time periods do not show the difference, it was found that the average starting distance of pedestrians' avoidance behavior is longer during a pandemic (with a significant difference in ANOVA), which may reflect people's awareness of 'distancing'. Therefore, we divided avoidance behavior into two categories, PSA (personal spacing avoidance) and LRA (long-range avoidance), using $3.66 \mathrm{~m}$ as the threshold for the avoidance distance, and then we analyzed these behaviors in details.

Then, ASCPP was developed to handle pedestrian behavior in ordinary and pandemic situations and has 16 behavioral rules based on ASPF. The model was validated by reproducing the times of PSA and LRA occurrences at both time periods. Next, we simulated the counter flows in the station atrium with five scenarios that dealt with the 'distancing' awareness, facial masks, and the obstruction of flow by the presence of people standing still, and estimated the effect of each scenario on the probability of proximity under the condition of $1 \%$ contagious people in the population. In particular, a t-test was conducted for the 'distancing' awareness, and a significant difference was confirmed.

The conclusion summarizes the findings from the series of works. Through this study, we have gained the prospect to develop a feasible methodological framework for pedestrian agent modeling and simulation that is consistent with the data survey to contribute to spatial considerations during the pandemic. The future challenge concerns larger-scale data collection. 